\title{
Black Money in India: Retrospect and Prospect
}

\author{
Arindam Gupta \\ Professor, Department of Commerce with Farm Management \\ Vidyasagar University, Midnapore, West Bengal, India \\ E-mail: arindamgupta69@gmail.com
}

Received: June 18, 2018 Accepted: August 29, $2018 \quad$ Published: September 13, 2018

doi:10.5296/ifb.v5i2.13291ＵRL: http://dx.doi.org/10.5296/ifb.v5i2.13291

\begin{abstract}
The paper makes a review of the attempts of the earlier governments to control black money through various measures vis-à-vis those taken by the present government. The paper finds some leniency in the recently declared Electoral Bond scheme otherwise such other measures of the present government appear to be more focused and reasonably effective. Demonetization was criticized due to the fall-out on the economy in general and its failure as an economic measure to curb black money in particular. The government remains successful in signing too the long awaited Tax Information Exchange Agreement with countries known as tax havens. It is implementing the new Black Money Act. Thus, not remaining exclusively dependent upon tax amnesty schemes like that of the previous governments; the present government has taken a few stern measures in pursuit of fulfilling the ruling political party's election promise to curb the black money menace. Appointment of anticorruption authority or ombudsman following the required legislation having passed under the pressure of an apolitical social movement is the need of the hour. The already existing Prevention of Corruption Act should be suitably amended as proposed, thus not to retain the same any more as a blunt legal weapon to restrain corruption engineered black money.
\end{abstract}

Keywords: Black money, Corruption, Tax evasion, Hawala, Demonetization, Tax amnesty schemes 


\section{Introduction}

Black money is currently a big issue in India. It got momentum when the ruling political party in the present government at the centre had announced to tackle the issue of black money, particularly which stashed in foreign soil, with utmost priority as a part of its election promises. Till recently the present government has brought in a few new legislations and also adopted measures against black money. This has established the honest intention of those who run the government to stand by the election promise after coming into power before the people. But no other measure is at par in order of importance and effect like demonetization which the government took exactly in the midst of tenure in November 2016. The measure remains the most controversial decision of the present government's tenure till now although the principal objective of the same, as announced by the prime minister, has been to wipe out the black money accumulated within the country. The government has been really struggling to recover from the fall-outs of demonetization when another serious issue like the fugitive economic offenders came out. A number of such incidents having unfolded particularly from the beginning of 2018 have shaken the banking industry of the country which was otherwise doing well. The government to prove its proactiveness against these persons has to at least act in such a manner including passing a fresh legislation that fugitive economic offenders need to be tackled on a priority basis (Note 1). This has also diverted the public attention from the government's serious agenda against black money. In spite of facing an allegation like conspiring against political opponents, the present government has brought charges very recently against some influential and powerful political figures of the country under the Undisclosed Foreign Income and Assets (Imposition of Tax) Act, popularly known as the Black Money Act, 2015 (Note 2). In this economic and political background of the country, an attempt has been made to look into the measures of so many previous governments at the centre in India since her independence to tackle the issue of black money vis-à-vis the measures of the present government. Also an academic review of these decisions is made to conclude the paper.

\subsection{Black Money in India: Sources}

Where does black money exist? If black money could be located by the law enforcing agencies that would have turned into the mainstream economy converting itself into what is white or normal money. But, black money is like an intangible. That is why black money is difficult to estimate although the researchers and the government too have attempted to estimate the black money in a country's economy. Significant difference among such estimates exists. However no one can deny that there is a parallel economy in the form of black or shadow economy side by side of the mainstream; money from the former significantly affecting the latter and in course of time gets naturally mixed with the latter. Thus, black money may exist within the country's soil in which it is generated and also goes beyond its boundary through various channels.

The Government of India has come out with one White Paper in 2012, defining black money as assets or resources that have neither been reported to the public authorities at the time of their generation nor disclosed at any point of time during their possession. The said White Paper has identified the following transactions responsible for generating black money (Govt. 
of India, 2012):

- Manipulations of accounts for tax evasion,

- International transfer pricing,

- Cash transactions in gold and jewellery,

- Real estate transactions,

- Transactions in not for profit sector,

- Informal sector and cash economy,

- $\quad$ Trade based money laundering, and

- Bribery in public procurement.

\subsection{Black Money Generation in Its Most Natural Route of Tax Evasion}

Concealment of income in the days when there was no PAN (Note 3) or PAN not required to be declared with investments had been very common. Traditionally, there had been much evasion of sales and other local taxes. A proportion of trade was therefore turned into black, escaping indirect and direct taxes. Over the years, a lot of ordinary citizens created black money by not paying taxes properly. Doctors, small businessmen, real estate dealers, engineers and even the teachers, engaged in private tuition or coaching, all joined the tax evasion process. There has been a tendency among a section of people not to file income tax return separately on the pretext of TDS on their declared income in the hands of their employer disbursing salary or the banks paying interest on their investment. Many people furnish the prescribed form $15 \mathrm{G} / \mathrm{H}$ to these banks for no TDS from interest income on fixed deposits, not knowing even the implication of such a form. The Income Tax department has however cautioned citizens that the same is applicable only for those who are not liable to pay any additional income tax for such income (Note 4). So, as perceived traditionally, black money is accumulated because of tax evasion from a huge number of citizens from all walks of life.

\subsection{Corruption and Black Money: The Potentiality of Prevention of Corruption and Lokpal Acts}

Corruption has been a part of the Indian society which starts from a meagre amount of bribe in any government office for getting a service in time although it is within the right of the person paying such bribe to get such service. Corruption also makes an easy entry in time of need to get some favour when bribe is paid for turning a non-entitlement into an entitlement. Corruption thus has a wide span from giving away contracts to giving away jobs. Further, the financial scams also involve high amount of unaccounted money in form of corruption. The case of economic offenders involving bank fraud and stock market fraud involve corruption of huge amount in particular. Unfortunately, scams and frauds can be identified since the Nehruvian period (17 years) (Note 5) to the period of the present government. But the previous two UPA governments remain most infamous for the scams and corruptions taking a 
new height and dimension during an about 9 year total tenure. Biggest of the lot has been the $2 \mathrm{G}$ Telecom scam involving an estimated amount of ₹ 1.76 trillion (Note 6).

In this perspective, the Prevention of Corruption Act (POCA, 1988) and Lokpal (Note 7) movement should be worth-mentioning. POCA, as introduced in 1988, is basically a measure to combat corruption of the public servants in government agencies and most vulnerable public sector businesses with the aim of forfeiture of property acquired by public servants through corrupt means. Public servants, as per the Act, include any person in the service of the government, any judge, or any person employed in a corporation owned by the government. The Act provides for formation of enquiry committee as to be headed by highly ranked police personnel whenever any such case of corruption will arise. The enquiry committee will submit its report to a special court as in the extant form of the Act there exists a provision for the special court to be appointed. The judge of the special court will give the verdict. There is a long pending amendment of the Act for which an Amendment Bill was placed in the Loksabha (Lower house) (Note 8) in 2013. After passing almost three years in a stage of transit, it got referred to a Select Committee of Rajyasabha (Upper house) in 2016. The amendment seeks to criminalise bribe-giving unambiguously and introduce the term, 'undue advantage' to refer to the benefit gained by the public servants by replacing different terms like 'illegal gratification', 'pecuniary advantage' or 'valuable thing'.Further, the other noteworthy amendment is the imposition of time limit on the trial period on the special court judge with an upper limit of maximum four years. The government could bring the said Bill to both the houses of parliament on April 04, 2018, but it was not passed. This indicates the lack of political will in reshaping the much needed Act. A general tendency of not attaching a suspected case to the provisions of POCA has also remained a trend till now.

The idea of an anti-corruption body and an ombudsman to look into corruption allegations against administrators, including legislators, had been floating around for over five decades before the passing of the Lokpal and Lokayuktas Bill, 2013, in both the houses of parliament in December, 2013 and becoming an Act from January, 2014. The Act allows formation of Lokpal at the centre and Lokayuktas at the state-level. The states are supposed to institute Lokayukta within one year of the commencement of the Act. The Lokpal, consisting of a chairperson and a maximum of eight members, is supposed to oversee all categories of public servants, including the prime minister, except the armed forces. The Act incorporates provisions for attachment and confiscation of property acquired by corrupt means even while the prosecution is pending. Another distinguishing feature of the original Act has been its power to prosecute independently. However, after the amendment, a law enforcement agency such as the CBI or the Lokpal will have to seek the government's permission to prosecute. In spite of being made an Act under the pressure of the so-called whistleblowers, the previous and the present governments have not been so keen in its implementation as alleged (Note 9).

Corruption remains the greatest contributor towards generation of black money in the country. There have been announcements to root out corruption in the past, but these seem to be mere political and habitual without any sustainability. "When it comes to dealing with black money in the country, there is this triad that needs to be broken. That triad is of corrupt politicians, corrupt businessmen and a corrupt administration. That needs to be broken.....And, that can 
only be broken through social movements..." (Arun Kumar quoted in The Economic Times, Mumbai, India, 2017, Dec. 15).

\subsection{Black Money and Its Travelling Abroad in the Hawala Route}

But, black money is generated through the two traditional routes like avoidance of taxes and corruption as discussed above. But, investment of the generated black money remains a headache for the hoarders. Hawala (Note 10) is a route through which black money travels overseas to safe havens for getting invested in different ways including in bank accounts after being converted into foreign currency. The money again returns to India by a similar route. It is now available for investment in 'black' assets which could be production entities, real estate, gold, jewellery, etc.. As foreign banks particularly engage in such type of transactions without questioning the depositors about the source of money, these banks also do not furnish any report on the ground of confidentiality. In the last few years, names of Indians and others who have accounts in foreign banks in Switzerland, France, Panama, etc. have come out due to the efforts of the whistleblowers. Hawala route is also largely used in building terror networks and initiating attacks on their targets. 'Black hawala' refers to the illegitimate transactions, specifically hawala money laundering associated with some serious offence such as narcotics trafficking and fraud. Hence, the issue of illegality in the nature of hawala route of transacting black money could be subjected to other related laws of the land too apart from the Income Tax Act as mentioned later in the paper.

As early as in 1991, the Jain hawala scandal had exposed the role of the multinational corporations using the hawala payment channels to pay-off bribes to politicians and bureaucrats in the country. Besides, hawala is sometimes also used by the workers employed in difficult areas to send their earnings to their family members speedily and efficiently. The route is also used by rich people to send their undisclosed income to countries like Mauritius for investment from there which will have no capital gains tax. The same money can in turn be invested from there even in the stock exchanges in India through the foreign fund managers. Another form of hawala is money being sent to Singapore where banks invest it for the owner but without his name, to be in turn invested in India (Note 11).

\subsection{Black Money Estimates for India}

Through successive announcements from the government directly or from important personalities in the banking sector of the country as also followed by newspaper reports, an impression is created that black money is kept abroad only. Black money lying in foreign accounts is estimated to be around \$1.4 trillion in 2009 (Vaidyanathan, 2009). In another published report of the Washington-based Global Financial Integrity (GFI), the said figure is estimated to be $\$ 3.4$ trillion which is nearly three times higher at the same time. Thesaid report is based on an empirical study on the transfer of black money from India from 1948 to 2008. It is concluded with the observation that "Illicit flows from India are more likely to have been driven by a complex interplay of structural factors and governance issues than they are by poor macroeconomic policies" (Kar, 2011). The study has advised the policymakers to ensure customs reforms and other regulatory oversight leading to significant improvements in 
governance necessary to shrink the underground economy. In any case, all these estimates are compiled till 2009 and corruption has gone up since then in the country.

In another such estimatebased on data from the IMF and BIS from 2013by three Bank of Italy economists, global black money as stashed in tax havens is $\$ 7$ trillion dollars. India's share is found in between $\$ 4$ - $\$ 181$ billion which is however a very wide range (Pellegrini, Sanelli, \& Tosti, 2016). The reason is that two different methods have been used in such estimation. One of the two methods assumes that the amount stashed away could be in the same ratio to that of the country's share of GDP in the global GDP. India's such share being $2.5 \%$ in 2013 amounts to about $\$ 152-181$ billion (₹ 8.9-10.5 thousand billion). In the second method, the amount stashed away from a country could be equal to its declared assets. India's such share being $0.07 \%$ of the total in 2013 , amounts to $\$ 4-5$ billion (₹ 330 billion). But a representation that a very big amount of black money is lying outside the country would divert us from a crude reality that a much bigger amount is lying within the country and continuously getting generated inside it. "Only 10 per cent of the black income generated annually accrues on foreign shores; 90 per cent is in the country. The annual generation of black income is 50 per cent of GDP or ₹ 65 thousand billion. A part of it is consumed and the rest is saved. A part of these savings is sent abroad through hawala transactions, and on mispricing of trade and illegal activities. Thus, a bulk of black savings is in India and not abroad" (Kumar, 2014).

\section{Method}

The data period of analysis of the subject is from one year prior to independence of the country from the British rule, i.e. 1946 till recently. But the total period has been bifurcated into 1946-2014, and 2014- 2018. Mr. Narendra D. Modi became the prime minister of India, being the leader of Bharatiya Janata Party (BJP) and National Democratic Alliance (NDA), on May 26, 2014 after winning the parliamentary election by a comfortable margin. Thus, this date is the cut-off in 2014 which actually bifurcates the total study period.

The measures as taken by all the previous governments mostly led by the Congress singly or in an alliance are considered first. After the end of the monopoly of Congress as the political ruler of the country in 1977, an alliance of a few political parties in the name of Janata Party led the government. The main unit of Congress as renamed after its leader Ms. Indira Gandhi as Congress (I), after its division into a number of factions, regained power in 1980. Congress again lost political control in 1989 to a coalition of parties named as Janata Dal (Party) as led by Mr. V.P. Singh which did not last full term, and also later in 1998 to the previous NDA as led by Mr. A.B. Vajpayee. Measures or steps taken against black money during the tenure of all these governments are taken into consideration. Vis-à-vis the measures taken by the present BJP (or, NDA) ruled government are considered. A theoretically argued logical conclusion of the measures is made. Repetitive measures like investment in gold bond or amnesty schemes like voluntary income disclosures remain under focus of analysis.

Data and information are obtained from various newspaper reports including the leading economic dailies in India. Opinions of the leading economists and experts on the subject have been consulted and quoted. Besides, reports of committees, RBI notifications, Ministry of 
Finance notifications, Income Tax department notifications, and facts and figures as obtained from various such sources have been used. The empirical studies of Kar (2011) and Pellegrini, Sanelli and Tosti (2016) have also been reviewed and referred above.

\section{Observations}

\subsection{Measures to Control Black Money: Taking an Account Historically in India till May, 2014}

The history of black money in India dates back to the pre-independence days. In 1946, the then British government had banned 10000 rupee notes as introduced in 1938. However considering the then price level it is understandable that the common man was not affected by such government action. The background of such action was World War II, which had just got over. Businessmen in India made huge profit by supplying the necessities during war time at an exorbitant price. They were concealing their profits from the tax department. As per the newspaper reports, old currency notes to the value of ₹470 million had been deposited across India as a fall-out of the note ban.

For a while after 1946, black money ceased to be a major issue. The demonetizations that took place were technical, dealing with the currencies of the native states before their merger with any province or conversion into a provincial state. In 1949 Kutch's koris, which were pure silver and thus causing problems in the bullion market, were converted. Similarly, Hyderabad's Osmania sicca, a 148-year-old currency, was converted to Indian rupees in 1957. In 1963-64, the old annas and pice coins were converted to paise (Note 12), also a technical demonetization (Doctor, 2016).

The first systematic attempt to evolve a tax system in independent India started with implementation of the report of Taxation Enquiry Commission in India in 1953. Yet the personal income tax rates were extraordinarily high during 1950-80. "With Indira Gandhi's 'socialist' phase being ushered in during 1970-71, the bottom rate went up to $11 \%$ and the top rate to an amazing $93.5 \%$, which rose within a few years to $98.75 \%$.... The entry level rate dropped to $20 \%$ in $1990-91$ and further to $10 \%$ when Chidambaram presented his 'dream budget' in 1997-98. The rates have remained the same since then.....various surcharges and cesses have periodically been added or sometimes removed" (Sinha \& Raghuraman, 2008).

In 1951, the first Voluntary Disclosure Scheme was announced as an amnesty as per which an individual was allowed to bring into book unaccounted cash before August 31, 1951. This scheme is also known as Tyagi scheme after the name of Mr. Mahavir Tyagi, the then minister for revenue and expenditure who had announced the said scheme. An individual was to give intimation to the ITO on the assurance of neither any penalty nor any prosecution under the tax law by paying the backlog taxes. The government's mission of eliminating black money generated through rampant black marketing during the World War II was proven to be largely successful.

The next noticeable amnesty scheme was exactly after 14 years in the year 1965 . The scheme is named Sixty-forty scheme as per which an individual could pay $60 \%$ of any previously undisclosed income by declaring it now and retain the balance $40 \%$. Tax could be paid in two instalments over six month. The declarations were kept confidential which were prohibited 
from production even in any court proceedings.

Not obtaining however much success like that of the 1951 scheme, the government introduced Finance (No. 2) Act to offer a second scheme in 1965. This scheme allowed the evaders to disclose their unaccounted incomes of any year up to March 31, 1966. As per the scheme an individual was allowed to pay tax as per the 1965-66 slab rates instead of the $60 \%$ flat rate of the earlier scheme of the year lowering the net tax liability. Tax was payable on the disclosed incomes for various years taken as a single block and could be paid in instalments extending over four years.

In 1965 the government went on declaring a third scheme in form of investments in the name of National Defence Gold Bond. Persons subscribing to these bonds were assured of confidentiality. The gold bonds were having a 15-year term and redeemable in gold. Such income could be invested in these bonds which were not assessed to tax before October 20, 1965. Such income could be invested which were not detected by the ITO before the date of subscription of gold towards the bonds.

In case of National Defence Remittance Scheme, which was also announced in 1965, the non-residents making a gift of foreign exchange by way of remittance under the scheme to any Indian resident were exempt from paying the gift tax. Gift tax existed in India from 1958 to avoid tax evasion by an individual in form of gifts to siphon income or asset as undisclosed till then to any other individual not falling under the category of blood relatives or family.

The Voluntary Disclosure Scheme of October 1975 was another amnesty scheme announced after 10 years of the 1965 amnesty schemes for giving the tax evaders another opportunity for declaring their accumulated unaccounted income or wealth. In the scheme, the government assured such individuals from the fear of levy of interest, penalty, or prosecution under the various direct tax enactments or the Gold Control Act. Tax rates as asked to be paid on disclosed income were 60 per cent in case of companies and at slab rates of $25 \%, 40 \%$ and $60 \%$ in the case of others.

In 1978, a scheme for demonetization of currency notes was undertaken by the government to remove black money supposedly held in high denomination currency notes of ₹1000, ₹5000 and ₹10000. Reportedly the Governor of RBI was made a party to the decision in spite of his strong personal reservation against the decision. An ordinance was promulgated by the then new non-Congress political managers of the country. The government version as publicized was that high-denomination notes were facilitating the illegal transfer of money for financing transactions and also being used for illegal purposes. In spite of a bumper harvesting season agricultural prices were much higher at that time. Massive imports of edible oil had failed to bring down prices of the mustard oil. The outcome of such demonetization decision could not be obtained in figures that much in the published documents. A reference is obtained in 2016 when the chief economic advisor of State Bank of India had submitted a fact in writing about the government decision in 1978. This was obtained exactly a week later from declaration of the current demonetization decision on November 14, 2016. Not explaining the source, it was said that $25 \%$ of the demonetized currency notes in possession of rich businessman in 1978 did not return to the banking system at that time (Ghosh, 2016). 
In 1981, a unique scheme in the name of Bearer Bond was announced in which bonds with a face value of ₹ 10000 redeemable after 10 years at ₹ 12000 was issued. No person subscribing to these bonds was required to disclose the source of fund. Further, an individual investing in such bonds would not be dragged into any proceeding relating to an offence or imposition of penalty. Thus, the amount of black money invested in these bonds had become white in ten years, in the process earning a tax-free premium of $20 \%$.

Seven CBDT circulars were issued between June 26, 1985 and February 17, 1986. These allowed tax evaders to disclose their unaccounted incomes and wealth of any year before March 31, 1986 and pay due tax on it. Hence, these were also kind of amnesty schemes in which waiver of penal interest and immunity from penalties was assured. However, no immunity in respect of excise duty, sales tax, etc. was sanctioned. The scheme was extended up to March 31, 1987.

Under the Voluntary Deposits (Immunities and Exemptions) Act 1991, NHB Deposit Scheme was offered for effective economic and social planning. Individuals were given immunity from disclosing the nature and source of such deposits. The government had declared that $40 \%$ of such deposits would be credited to a special fund for financing slum clearance while the balance could be utilized by the depositors.

Remittances of Foreign Exchange and Investment in Foreign Exchange Bonds (Immunities and Exemptions) Act, 1991 provided that individuals having received foreign exchange under a RBI notified remittance scheme were not to disclose the nature and source of such remittance. Further, this fact was not made admissible too as evidence in any proceeding relating to an offence or penalty under the various direct tax enactments, FERA, FCRA, etc. The two schemes, viz., the Remittances in Foreign Exchange (Immunities) Scheme, 1991 and the India Development Bonds Scheme, 1991 were introduced following the provision as said above and also the RBI notifications dt. September 20, 1991 and September 21, 1991 respectively.

The Gold Bonds (Immunities and Exemptions) Act, 1993 provided for depositing a minimum of $500 \mathrm{gm}$ of gold without any maximum limit in the five-year Gold bonds which would remain open for two months for investment. Investors were issued certificates with a guaranteed ₹40 interest for each gm of gold deposit as total amount of gold so deposited would have to be melted. Investors would be given immunity from being asked as to how the gold was acquired or the source of funds behind such acquisition. Besides, they were also spared from any scrutiny under the provisions of the Wealth-tax Act, Gift-tax Act, Income-tax Act, Customs Act, FERA, and FCRA. The government managed to mobilize a little over 41 tonnes valued then at ₹ 18.07 billion through this scheme.

The Voluntary Disclosure of Income Scheme (VDIS), 1997 which came into force from July 01, 1997 has been the most successful amnesty scheme in the latter years when black money deposition in the country had considerably increased. As per this scheme, any individual could declare so far undisclosed income related to any assessment year upto the year, 1997-98 till December 31, 1997. Tax payable on the disclosed income in respect of any assessment year was at the rate of $30 \%$. In case of companies and firms, such rate was fixed at $35 \%$. Tax payable under the scheme was to be paid before filing the declaration with the proof of payment of tax 
attached. No disclosure of wealth was allowed under the scheme. The scheme allowed an arbitrary date of April 01, 1987 for showing the value of the jewellery items. So, if anyone bought gold in 1997 (the year of the scheme), not only could s/he say s/he bought it before 1987 to reduce its valuation (for tax purposes) to around half! The policy of declaring black assets in the form of property was more curious, and no proof of purchase or valuation was asked for. The scheme granted tax defaulters indefinite immunity from prosecution under the FERA, 1973, the Income Tax Act, 1961, the Wealth Tax Act, 1957, and the Companies Act, 1956. Over 3,50,000 people disclosed their income and assets under this scheme, which brought a revenue of ₹78 billion to the government. The CAG had severely criticized the scheme apprehending the genuine taxpayers of the country to be likely demotivated by such amnesty scheme after obeying the existing law in time and without failure.

Table 1 below presents the outcome of the measures as reported in various relevant sources.

Table 1. Outcomes of previous government measures against black money

\begin{tabular}{|c|c|c|}
\hline Year & Measure & Outcome \\
\hline 1951 & $\begin{array}{l}\text { Voluntary Disclosure } \\
\text { Scheme (Tyagi Scheme) }\end{array}$ & $\begin{array}{l}\text { ₹702 million of income disclosure and ₹200 } \\
\text { million of tax collected }\end{array}$ \\
\hline 1965 & Sixty-forty Scheme & $\begin{array}{l}\text { ₹521.8 million of income disclosure and ₹300.8 } \\
\text { million of tax collected }\end{array}$ \\
\hline 1965 & Income Disclosure Scheme & $\begin{array}{l}\text { ₹1450 million of income was disclosed and } \\
₹ 194.5 \text { million of tax was collected }\end{array}$ \\
\hline 1965 & National Defence Gold Bonds & ₹180 million of income was disclosed \\
\hline 1965 & National Defence Remittance Scheme & ₹700 million of income was disclosed \\
\hline 1975 & Voluntary Disclosure Scheme & $\begin{array}{l}\text { ₹7440 million of income was disclosed and } \\
\text { ₹ } 2410 \text { million of tax was collected }\end{array}$ \\
\hline 1978 & Demonetization & $\begin{array}{l}25 \% \text { of the ₹ } 1000 \text { notes did not return to the } \\
\text { banks, thus eliminated }\end{array}$ \\
\hline 1981 & Bearer Bond & $\begin{array}{l}\text { ₹9.64 billion of fund was disclosed through } \\
\text { investment in such bond }\end{array}$ \\
\hline $1985-1986$ & Seven CBDT Circulars & $\begin{array}{l}\text { ₹ } 107.78 \text { billion of income was disclosed with a } \\
\text { collection of ₹ } 5 \text { billion income tax }\end{array}$ \\
\hline 1991 & NHB Deposit Scheme & $\begin{array}{l}\text { ₹600 million of fund was invested in such } \\
\text { deposit scheme }\end{array}$ \\
\hline 1991 & $\begin{array}{l}\text { Remittances in Foreign Exchange } \\
\text { (Immunities) Scheme, } 1991 \text { and } \\
\text { India Development Bonds Scheme, } 1991\end{array}$ & $\begin{array}{l}\text { The Remittance Scheme brought in about ₹ } 22 \\
\text { billion while India Development Bonds ₹ } 45 \\
\text { billion }\end{array}$ \\
\hline 1993 & Gold Bond Scheme & $₹ 18.07$ billion of fund was invested \\
\hline 1997 & $\begin{array}{l}\text { Voluntary Disclosure } \\
\text { Income Scheme }\end{array}$ & $\begin{array}{l}\text { Over } 3,50,000 \text { people disclosed their income and } \\
\text { assets.₹ } 333.39 \text { billion of income was disclosed } \\
\text { and ₹ } 95.84 \text { billion of income tax was collected }\end{array}$ \\
\hline
\end{tabular}

Note. Compiled from the idea and information obtained from Ghosh (2017) with permission, however supplemented with information collected from various other sources. 
Besides the above-mentioned measures, in January 2014 the government announced to discontinue all bank notes printed prior to 2005 and replaced those currency notes with new equivalent notes for security reason. This is referred here just as a related development although not particularly being any kind of measure against black money.

\subsection{Measures of the Present Government to Control Black Money from May, 2014 till Recently}

The Wealth Tax Act, which was introduced in 1957 was thoroughly revised in 1993 on recommendations of the Chelliah Committee (Note 13), was completely removed from the financial year 2015-16. The loss of revenue due to the abolition of wealth tax as announced in the union budget of 2015 was expected to be compensated by the levy of additional surcharge on high income earning assesses. According to the finance minister, only a nominal amount of revenue was so far collected from the levy of wealth tax. But this levy had created a significant amount of compliance burden on the taxpayers as well as administrative burden on the Income Tax department.

India's efforts to bring back black money stashed abroad have been reportedly hampered by the bilateral Double Taxation Avoidance Agreements (DTAAs). Most countries have earlier refused India's request of eliminating the confidentiality provision including a majority of them not intending to share such information until a court case comes up. The Undisclosed Foreign Income and Assets (Imposition of Tax) Bill, 2015, popularly known as Black Money Bill was passed in the parliament in the same year and became an Act. As per this Act, tax at the flat rate of 30 per cent will have to be paid on all foreign income without any exemption, deduction, and set off or carry forward losses. Further, undisclosed holdings of less than ₹ 0.5 million at any time during a year not reported out of oversight or ignorance will not attract penalty or prosecution. The government has empowered itself through this Act to enter into agreements with other countries for the exchange of information, recovery of tax and avoidance of double taxation. As an outcome, Switzerland has agreed to share information on accounts by Indians in Swiss banks from January 1, 2018 as per Tax Information Exchange Agreement (TIEA). This arrangement is supposed to start from September, 2019 onwards as per TIEA. Already rapid decline in the deposits in such Indian accounts caused India's rank slipping down to $75^{\text {th }}$ position in 2017. The Indian government has been successful in mounting pressure upon the government there through the international bodies like OECD or G-20. Although problem remains in searching for personal names because of the trick to create "shell" companies and make transactions of money in such companies' names. The current government had however taken a praiseworthy effort of deregistering many such companies as part of its drive against black money. Nearly 0.226 million companies have already been deregistered and around 0.309 million directors associated with these companies have been disqualified (Source: The Economic Times, Mumbai, India, Jan. 16, 2018).

The Benami Transactions (Prohibition) Amendment Bill, 2015 was introduced in the parliament on May 13, 2015 and was notified on August 10, 2016. A benami transaction, as defined in the existing Benami Transactions Act, 1988, is a transaction in which i) the property is held by one person and paid for by another; or ii) it is held in a fictitious name; or iii) the owner of such property is unaware of or denies having knowledge of such ownership; or iv) the 
person financing such transaction is not traceable. The Act prohibits such benami transactions and provides for confiscating such benami properties. The Bill seeks to establish adjudicating authorities and an appellate tribunal to deal with benami transactions and to specify penalty. The penalty for providing false information may be upto a rigorous imprisonment of five years and a fine upto $10 \%$ of the fair market value of the benami property. Certain session courts would be empowered as special courts for trying the punishable offences.

Income declaration scheme (IDS), 2016 was an amnesty scheme introduced by the government in the union budget of 2016 to bring back black money into the system. One time opportunity was given to all the citizens having not declared income correctly in the earlier years for declaring such income. But they were to pay tax and penalty aggregating to $45 \%$ of the amount of undisclosed income. The government had issued simultaneously a stern warning to those evading tax, announcing a $90 \%$ tax and a penalty of 7 years in jail if overseas assets were not declared within the 4-month compliance window beginning on June 01. Payment of taxes was permitted in three instalments, the last being in September 2017. The scheme guaranteed immunity from prosecution under the Income Tax Act, Wealth Tax Act, 1957, and the Benami Transactions (Prohibition) Act, 1988. It further ensured that declarations under it not to be subjected to any scrutiny or enquiry except under the POCA, 1988. The scheme led to disclosure of ₹652.50 billion of undisclosed income from which it brought in one-time extra income tax revenue of around ₹300 billion. The finance minister said in support of the scheme that the earlier VDIS could not penalize the declarants and allowed them rather to value the assets declared at the 1987 market price rather than the then current rate (Source: The Economic Times, Mumbai, India, 2016, Oct. 01).

In view of the demonetization decision of the government in November, 2016 for the 500 and 1000 rupee notes the government represented in the Supreme Court that an estimated ₹4-5 thousand billion of black money amounting $25 \%$ of the total value of the banned currency notes could be wiped out from circulation. But the effort seems to have failed as the RBI reporting later of only $1 \%$ of the cash not returning in the system instead. The reasons behind such failure could be explained on the following grounds:

- a defiant stand of the corrupt black money hoarders to buy time by siphoning black money either through their own bank accounts or those of others and face challenges of income tax later,

- a major chunk of black money remaining already invested with financial institutions outside the country,

- black money remaining also hoarded intelligently in bought land and housing property, gold and jewellery, etc.,

- the allegation as the corrupt bank officials supplying valid notes against demonetized currency notes during the window period in exchange of commission, and

- siphoning of a significant amount of anticipated black money to a safe shelter of others' bank accounts like Prime Minister People's Wealth Scheme [Pradhan Mantri Jan Dhan Yojana or PMJDY (Note 14)] accounts. 
PMJDY website based progress report if analyzed reveals an average deposit balance per such account mainly held by the poor and so-far unbanked population increasing much after demonetization to ₹2643. This was just ₹1780 on November 02, 2016 as last obtainable just before the announcement of demonetization decision on November 08, 2016. Hence, the rise in average balance on the expiry of the window period seems to be quite abnormal. Besides, there are reports that co-operative banks and credit societies, that maintain most of the records manually, had manipulated the process of issuing issued fixed deposit receipts in back dates. The real investors received new currency notes in due course after paying a cut to those in whose names such deposit certificates were issued against receipt of banned currency notes after opting for a pre-mature closure of the same (Vij, 2016). Thus, the government could not check these major channels of manipulation apart from many other tricky channels like advance salary payment before the end of the window period on December 30, 2016.

Prime Minister Poor Welfare Scheme (Pradhan Mantri Garib Kalyan Yojana or PMGKY) is an amnesty scheme of the government launched in December 2016 after the IDS having been announced earlier in the same year not meeting the expected outcome. The scheme provides an opportunity to declare unaccounted wealth and black money after paying a fine of $50 \%$ on the undisclosed income. An additional $25 \%$ of the undisclosed income is invested in the scheme which is to be refunded after four years without any interest. Valid from December 16, 2016 to March 31, 2017, the scheme can only be availed to declare income in the form of cash or bank deposits in the bank accounts with in the country and not in any form of jewellery, stock, immovable property, or deposits in overseas accounts. The scheme provides confidentiality like any other amnesty scheme and averts prosecution of the individual. According to the Income Tax department, those who are raided and found not having made with declaration under PMGKY or under the income tax returns will attract 107.25 per cent tax and penalty. Even after that those who hold back their hidden income will face the highest penalty of 137.25 per cent.

Implementation of Goods and Services Tax (GST) which has been launched from July, 2017 by the government can also be treated to be an indirect measure of dealing with black money. It has also been earlier recommended for implementation by the experts as a preventive tax reform policy measure to restrict evasion of indirect taxes. GST being a destination based tax where the tax is applied at the point of supply or consumption will make tax evasion difficult. Companies will not have to file tax returns too with multiple departments, but there will be just one web-based form to file tax returns.

Introduction of electoral bonds in the Union Budget, 2018 has been so far the latest effort of the government to control black money that funds political parties in India. In fact, the scheme has in fact legalized contribution of black money to the political parties. Most political parties accept cash donations from anonymous sources. Currently, political parties are required to report any donation of over ₹20000 to the Income Tax department. But endowments coming by way of cash in smaller amounts make a much bigger total amount of collection of donation. Apart from this the political parties give special drive of collecting donations during election time. The government had already reduced disclosure limit for any such donation to ₹2000 and also directed any amount over this to pay by cheque or through the digital mode. But, through 
the electoral bonds the donors will have to take the banking route for donating. Thus, their identity is captured only by the political parties being the issuing authority of the bonds but they will not disclose the identity of the contributors. Further the scope of an unlimited amount of contribution in form of electoral bonds overrules the existing provision of corporate donation to political parties as per section 182 of the Indian Companies (Amendment) Act, 2013, maximum up to $7.5 \%$ of the average profit of the last three years. The existing provision for a company to disclose donation to a political party is also overruled by the new provision under section 13A of the Income Tax Act. As per the said section, the companies contributing through electoral bonds will not even be required to keep records of such donations. Thus, it snatches away the power of scrutiny of the Income Tax authorities of any such donation. "Major democracies have increasingly tightened disclosure rules. In the United States, there is a requirement to provide the name, occupation, employers and addresses of all individuals who contribute more than $\$ 200$ to political entities. In the UK, any contribution above $\$ 7500$ must reveal the name of the donor. By contrast, India, the world's largest democracy, electoral reform has legitimised financial opacity" (Varma, 2018).

Union Budget, 2018 has also legalized receiving foreign contribution by the political parties without any scrutiny by making necessary amendments in the Foreign Contribution Regulation Act, 2010. This has also been given a retrospective effect from 1976.

Table 2 below summarizes the actual and / or anticipated outcome of the measures of the present government.

Table 2. Outcomes of present government measures against black money

\begin{tabular}{lll}
\hline Year & Measure & Outcome \\
\hline 2015 & Black Money Act & ₹41.64 billion of income was disclosed and ₹ \\
& & 24.88 of income tax was collected \\
2015 & The Benami Transactions & Crackdown on benami transactions so far yielded \\
& (Amendment) Act, 2015 & ₹6 billion till mid-2017 \\
2015 & Abolition of Wealth Tax & Not estimated or obtained \\
2016 & Income Declaration Scheme & ₹652.50 billion of income was disclosed and \\
& & ₹300 billion of income tax was collected \\
2016 & Demonetization & RBI reported that only 1\% of the banned notes did \\
& & not return \\
2016 & Pradhan Mantri Garib Kalyan Yojana & ₹50 billion deposited under the scheme \\
2017 & GST & Figures cannot be separately estimated \\
2018 & Electoral Bonds & Figures cannot be estimated or obtained \\
\hline
\end{tabular}

\section{Discussion}

One may reasonably argue that black money begets black money and the white will produce white. In the earlier days, black money generation could be attributed to such high rate of taxation in the country. But, in course of time this became a habitual offence with no serious threat from the government machinery keeping scope for out of the system (or, informal) settlements. And it keeps on adding to the black money kit as the country ranks in corruption 
perception index very high continuously (Note 15). The efforts to curb black money can be categorized into two types: aggressive and amnesty. Aggressive efforts include steps implementing the existing regulations proactively through imposing penalty, fine and other necessary criminal proceedings after search and seizure. Among the legislations already existing, the most prominent is the Prevention of Money Laundering Act, 2002. In addition, specific provisions under the Income Tax Act, 1961; POCA, 1988; and the Narcotic Drugs and Psychotropic Substances Act, 1985 could also be applied if the case so demands. Further, a non-resident Indian may be proceeded against under FEMA if there has been any concealment of income. Any non-payment or under-payment of tax is subject to interest and penalty as per the Income tax Act up to three times of the amount of tax evaded. "The civil and criminal liabilities for holding black money range from rigorous imprisonment for not less than three years and up to seven to 10 years, along with a fine" (Dey, 2014). Among the new legislations, the Black Money Act is considered noteworthy and aggressive in nature. Demonetization also being a too aggressive measure is not ideally operational and hence limited in applications across the world. The government should have been quick enough in applying data analytics and start scrutinizing cash deposits and transactions made after November, 2016 if it had to establish demonetization as a prudent decision.

Amnesty schemes have been announced maximum number of times including the landmark schemes like VDIS and IDS. Deadlines have been extended or valuation date for disclosure of assets has been made convenient in the amnesty schemes to attract the defaulters with the benefits of participating in such schemes. The government has also resorted to appeal to the sentiments highlighting patriotism, national defence, nation-building, concerns for fellow citizens, and lastly of course, fears of future strict enforcement. Application of amnesty scheme has another advantage. Once an asset or income is disclosed, the accrual of income on the same has to be disclosed by the individual in future income declarations. Although, the Supreme Court had asked the government to refrain from offering such amnesty schemes because such schemes would demoralize honest taxpayers. The CAG, the government's own audit unit, has also criticized these efforts in the strongest possible words. Some of these schemes have been specifically designed for targeted groups of people like those hoarding gold or foreign exchange, NRIs, etc.. History however shows, schemes without an amnesty on offer have hardly succeeded. Even the most successful could bring out black money of no more than 5\% of GDP when the most conservative estimates of black money range upwards of $30 \%$ of GDP (Khan, 2012).

In search and seizure action under section 132 of the Income Tax Act, the Investigation Wing of the CBDT has detected concealed income of ₹404.27 billion from 2006-07 to 2011-12 (Ghosh, 2017). The crackdown on benami transactions so far has yielded another ₹6 billion. Union Budget, 2017 had predicted an annual increase of $25.4 \%$ in income tax collections over revised estimate (RE) figures for 2016-17. RE figures for 2016-17 showed an annual increase of 23.3\% over 2015-16 actual estimates. These growth figures exhibit a considerable improvement in India's income tax base recently. The buoyancy in personal income tax, which can be obtained by dividing the growth in personal income tax by growth in nominal GDP, for financial years 2016-17 and 2017-18 (RE) is 1.95 and 2.11 respectively (Source: 
The Hindu, Chennai, India, February 01, 2018). Union Budget, 2018 has given us a figure of about ₹900 billion that has been collected excess by the government in the last two financial years on account of anti-evasion measures. The government attributed the increase in tax collection to the dual factors of demonetization of 2016 and income disclosure scheme of 2017 (Kishore, 2017). The government has already claimed that after demonetisation the Revenue department launched "Operation Clean Money" on January 31, 2017 with respect to about 1.79 million persons whose cash transactions did not appear in line with their tax profile. Online verification of such cash transactions was enabled and the information in respect of identified cases was made available in the e-filing window of the PAN holder (Note 16).

But, in the backdrop of the present government boasting of achieving success out of the measures taken by it, there are claims on the contrary as well. Many have expressed concern and doubt as to whether the government has adequate manpower to detect tax evasion and process the income tax files of a huge number of offenders within the stipulated time. The data provided by the finance ministry show a seizure of ₹ 10.03 billion only between November 2016 and May 2017 out of ₹175.26 billion of undisclosed income having unearthed. Earlier Income Tax department data show annual amount of seizures of around ₹7 to ₹8 billion from an undisclosed income of around ₹100 to ₹110 billion being unearthed since 2013-14. This reflects no significant rise in the seizures of illicit wealth, post-demonetization (Bose, 2017). The ongoing networking attempts of the government at least of the deposits held with the banks and financial institutions with the Income tax department using the unique citizen identity card (Aadhaar) (Note 17) and PAN seem to be thwarted due to an unmanageable population to be networked. The government could not yet finish the preparation of Aadhaar card for all its eligible population. The apex court of the country could not be convinced too about the necessity of Aadhaar linkage in the proposed context of JAM (Note 18). Till now the apex court had asked the government to make such linkage compulsory only in respect of its direct benefit transfers to the beneficiary accounts (Note 19).

Apart from collection of income taxes internally, there have been serious attempts from the present government to identify the money kept in tax havens outside the country by active lobbying. The government remains successful in signing too the long awaited Tax Information Exchange Agreement with countries known as tax havens. Under the directive of the Supreme Court, the present government submitted a list on October 29, 2014 in a sealed cover with the 627 names of Indians holding black money abroad. The Supreme Court also directed the government to share the list with the Enforcement Directorate and the Central Bureau of Investigation (Source: India Today, dt. October 29, 2014). In 2011, the Supreme Court, which has been monitoring the investigations into black money since 2009, had asked for complete disclosure of information on Indians holding black money abroad. But, the previous UPA government appeared not to be proactive enough. But, the content of the list is not yet known remaining sub-judice. Through information leakage, it is learnt that very influential political personalities are listed among the said 627 names. Thus, appointment of anti-corruption authority or ombudsman in the names of Lokpal and Lokayuktas without further dilution has become the real need of the hour. In respect of taxation measures, there should be cohesion between the aggressive measures and amnesty measures of the 
government and should remain continuing. The government's attempt of introducing the new Black Money Act and its implementation are in the right direction. The already existing Prevention of Corruption Act should be suitably amended as proposed, thus not to retain the same any more as a blunt legal weapon to control corruption engineered black money. The overall situation in respect of restraining black money has undoubtedly improved but still loopholes exist within the system.

\section{Acknowledgment}

The author expresses his gratitude to Dr. T.P. Ghosh, Professor of Finance, IMT, Dubai, UAE for his suggestions.

\section{References}

Bose, P. (2017). Sept. 02. Demonetisation Post-Truths. EPW Engage, 52(35). Retrieved from https://www.epw.in/engage/article/-demonetisation-post-truths

Dey, S. (2014). Nov. 10. Laws that regulate black money in India. Retrieved from http://www.business-standard.com/article/opinion/laws-that-regulate-black-money-in-india-1 14111000017_1.html

Doctor, V. (2016). Nov. 12. The cycles of demonetisation: A looks back at two similar experiments in 1946 and 1978. Retrieved from https://blogs.economictimes.indiatimes.com /onmyplate/the-cycles-of-demonetisation-a-looks-back-at-two-similar-experiments-in-1946-a nd-1978/

Ghosh, S. K. (2016). Nov. 14. Demonetisation and Note Burning. Business Standard. New Delhi.

Ghosh, T. P. (2017). Black Money Counterfeits and Demonetisation: An Indian Experience. Taxmann. New Delhi.

Government of India, Ministry of Finance. (2012). July 29. White Paper on Black Money. Retrieved from https://www.finmin.nic.in

Kar, D. (2011). April 9. An Empirical Study on the Transfer of Black Money from India: 1948-2008. Economic \& Political Weekly, XLVI(15), 45-54.

Khan, S. S. (2012). March 12. Tax Amnesties in India. Retrieved from https://taxindiainternational.com/columnDesc.php?qwer43fcxzt=NzU=

Kishore, R. (2017). May 24. Has demonetisation really boosted income tax collections? Retrieved from https://www.livemint.com/Politics/C4Q8mpskSbfEzmG8ZWBY9H/Can-wemeasure-demonetisations-impact-on-income-tax-collect.html

Kumar, A. (2014). Nov. 01. Secrecy in the name of privacy. The Hindu. Chennai. India. Retrieved from http://www.thehindu.com/opinion/lead/lead-article-secrecy-in-the-name-ofprivacy/article6553153.ece

Pellegrini, V., Sanelli, A., \& Tosti, E. (2016). What do External Statistics tell us About 
Undeclared Assets held Abroad and Tax Evasion? Bank of Italy Occasional Paper No. 367. Retrieved from https://papers.ssrn.com/sol3/papers.cfm?

Sinha, P., \& Raghuraman, S. (2008). March 04. Level of tax rates rose in Indira regime. Retrieved from https://timesofindia.indiatimes.com/business/india-business/Level-of-tax -rates-rose-in-Indira-regime/articleshow/2835227.cms

Vaidyanathan, R. (2009). Indian money in Swiss \& other banks is over Rs 70 lakh crore. Retrieved from http://www.dnaindia.com/business/report-indian-money-in-swiss-otherbanks- is-over-rs-70-lakh-crore-1244317

Varma, P. Kr. (2018). March 31. Nourishing The Black Economy. Times of India. Kolkata. India.

Vij, S. (2016). Nov. 14. 13 Ways In Which Indians Will Convert Their Black Money Into White Even After Demonetisation. Retrieved from https://www.huffingtonpost.in /2016/11/13/13-ways-in-which-indians-will-convert-their-black-money-into-whi_a_2160514/

\section{Notes}

Note 1. This led to the speedy clearance of one Fugitive Economic Offenders Bill, 2017 by Cabinet in March, 2018. It was placed in Loksabha (Lower house) but could not be discussed due to the logjam. Ultimately, an Ordinance was issued which the President signed on April 11,2018 . Offences involving ₹100 crore or more fall under its purview.

Note 2. On May 13, 2018, the Income tax department has issued four chargesheets against former Finance minister, Mr. P. Chidambaram and his family for possessing and operating several illegal assets and accounts in foreign countries as those were not disclosed in their 2016 Income Tax affidavit.

Note 3. Permanent Account Number (PAN) is a unique number given by the government to every Indian citizen who may be assessed for income tax. It is also used as a government identity card by the Indian citizens.

Note 4. Of late, the Income tax department has issued instructions to the banks for informing their customers through convenient ways that if his/her taxable limit exceeds the minimum exempted for paying taxes, $\mathrm{s} /$ he should refrain from furnishing such forms to the banks.

Note 5. Mr. Jawahar Lal Nehru has been the first Prime Minister of India since independence in 1947 until his death in 1964. He is naturally considered the architect of the initial economic, agricultural and industrial policies of the country in line of his dream of a "socialistic pattern of society" following a curious path of mixed economy in which the public sector and private sector both will have to play their respective roles.

Note 6. Although, the final verdict from the POCA Special Court in December, 2017 gave a clean chit to all those prime accused for inadequacy of evidence submitted by the CBI in support of its charge sheet. 
Note 7. Lokpal is a Sanskrit word, which means in English the caretaker of people. The Bill was introduced in the Indian parliament following massive public protests led by anti-corruption crusader Mr. Anna Hazare and his associates.

Note 8. Lower house (Loksabha) is more powerful of the two parliaments in India, the other of which is called Rajyasabha (Upper house). However for becoming an Act, a bill needs to be passed with majority at both the houses.

Note 9. In April 2017, the Supreme Court had to question the central government as to why it had not set up the Lokpal at the Centre and the Lokayuktas at the state level as mandated by Act. In March, 2018, the Supreme Court had also asked the chief secretaries of 12 states including Tamil Nadu, West Bengal, Jammu \& Kashmir, Telangana and Manipur, why they had not appointed any Lokayukta.

Note 10. It is basically an Arabic word which means a popular and informal value transfer system based not on the movement of cash. Money transfer without money movement can be an easy definition of hawala.

Note 11. These are known as "participatory notes".

Note 12. Paise is a minimum monetary unit, which can be measured as the 100th part of one rupee $(₹)$, the principal paper currency in India. Earlier, this existed in 1, 2, 5, 10, 20, 25, 50 units in form of coins. But, at present, only 25 and 50 units are permissible as legal tender in the country although the central bank has advised the holders to exchange these against rupee. Thus, this monetary unit is going to be obsolete in the country just like the other variants in coin form like koris, sikka, anna, etc.

Note 13. The Government appointed a Tax Reforms Committee (TRC) under Prof. Raja Chelliah to lay out agenda for reforming India's tax system. This TRC came up with three reports in 1991, 1992 and 1993 with several measures.

Note 14. PMJDY is a landmark in the history of the financial inclusion programmes in India which was introduced by the present government in August, 2014 just after assuming power in May, 2014. As of now (July11, 2018), about 320 million beneficiaries could open a bank account with an aggregate of ₹793.71 billion of deposits.

Note 15. India has been ranked $81^{\text {st }}$ in the global corruption perception index for 2017, released by Transparency International. This is a rank given among 180 countries and territories considered for their perceived levels of public sector corruption. The index uses a scale of 0 to 100 , where 0 is highly corrupt and 100 is very clean. India's score in the latest ranking, however, remained unchanged at 40. In 2015, the score was 38.

Note 16. Finance minister, Mr. Arun Jaitley gave a written reply to the Rajyasabha (Upper house) as quoted by PTI on March 22, 2018, retrievable fromhttps://timesofindia.indiatimes.com/business/india-business/demonetisation-succeededin-unearthing-black-money-preventing-corruption-arun-jaitley/articleshow /63420575.cms 


\section{Macrothink}

Note 17. Unique Identification Authority of India is a statutory body established under the Ministry of Electronics and Information Technology to look after issuing Aadhaar card and monitoring the same as unique identification number of every Indian citizen. It is a more authenticated document now for national identity than the Voter card which was earlier used as such.

Note18. The government-published economic survey had coined a new acronym, JAM ("Jan dhan - the bank account to be opened by the so far unbanked population under the PMJDY, Aadhaar - the unique citizen identity card, and Mobile - the phone"). The JAM agenda refers to the potential of tech-enabled cash transfers so as to allow the money to reach the hands of poor people directly without a scope of any pilferage. According to the finance minister, it has the potential to link all Indians into one common financial, economic, and digital space.

Note 19. As per the latest ruling of the Supreme Court of India as on March 13, 2018 opining on the issue of deadline in respect of Aadhaar linkage.

Non-English glossaries (The words are in Hindi, being the national language in India):

Benami stands for a property or investment acquired by an individual in others' name illegally siphoning own money,

Dal stands for political party,

Dhan stands for wealth,

Garib stands for poor,

Jan stands for people (or public),

Kalyan stands for welfare,

Lok stands for people,

Pal stands for caretaker,

Pradhan Mantri stands for Prime Minister,

Rajya stands for state (province),

Sabha stands for meeting (of representatives), and

Yojana stands for scheme.

Units of measurement used:

1 lakh $=0.10$ million and 1 crore $=0.01$ billion

Symbol used:

$₹$ is the symbol of Indian currency, Rupee.

1 ₹ is equivalent to 0.0147 US\$ (June 18, 2018). 
Abbreviations used:

$B I S$ stands for Bank for International Settlements,

$C A G$ stands for Comptroller and Auditor General (the government agency for audit in the government entities),

CBDT stands for Central Board for Direct Taxes (the apex government body for administration of direct taxes),

CBI stands for Central Bureau of Investigations,

FCRA stands for Foreign Contribution Regulation Act,

FERA stands for Foreign Exchange Regulation Act,

GDP stands for Gross Domestic Product,

GST stands for Goods and Services tax,

$I M F$ stands for International Monetary Fund,

ITO stands for Income Tax Officer,

$R B I$ stands for Reserve Bank of India (India's central bank),

$T D S$ stands for Tax Deducted at Source, and

UPA stands for United Progressive Alliance (an alliance of Congress-led political parties in India which ran the governments for two successive full terms just before the present government during 2004-2014).

\section{Copyrights}

Copyright for this article is retained by the author(s), with first publication rights granted to the journal.

This is an open-access article distributed under the terms and conditions of the Creative Commons Attribution license (http://creativecommons.org/licenses/by/4.0/). 